\title{
The Influences of Justice and Trust on the Organizational Citizenship Behavior of Generation X and Generation $\mathrm{Y}$
}

\author{
Amphaphorn Leelamanothum ${ }^{1}$, Khahan Na-Nan ${ }^{1} \&$ Sungworn Ngudgratoke ${ }^{2}$ \\ ${ }^{1}$ Business Administration Faculty, Rajamangala University of Technology Thanyaburi, Pathumthani \\ ${ }^{2}$ Department of Education, Sukhothai Thammathirat Open University, Nonthaburi \\ Correspondence: Amphaphorn Leelamanothum, 39 Moo 1 Rangsit-Nakhonnayok Rd, 12110, Thanyaburi, \\ Pathumthani. E-mail: jindamook@hotmail.com; amphaphorn_1@mail.rmutt.ac.th
}

Received: February 11, 2018 Accepted: March 21, $2018 \quad$ Online Published: April 19, 2018

doi:10.5539/ass.v14n5p60

URL: https://doi.org/10.5539/ass.v14n5p60

\begin{abstract}
This study aimed to study the influences of justice and trust on the organizational citizenship behavior. The questionnaire respondents were the workers at Rajamangala University of Technology. Data analysis was done through structural equation modeling to test the purpose model and compare between the groups via multiple groups analysis approach. It was found that justice and trust have a positive statistical significant influence on organizational citizenship behavior. Moreover, justice has a positive statistical significant influence on trust. Generation $\mathrm{X}$ and Generation $\mathrm{Y}$ differently perceive the influences of justice and trust on organizational citizenship behavior. Generation X paid attention to the influence of justice on the organizational citizenship behavior while generation $\mathrm{Y}$ paid attention to the influence of trust on justice, the chief will implement justice in the organization for both generations to build trust in the chief and the organization. This would lead to future achievements in the organization.
\end{abstract}

Keywords: generation, organizational justice, organizational trust

\section{Introduction}

As an employee in a university, what is expected from the organization is progress in career and suitable compensation, and opportunities to develop higher potential and knowledge. It is expected of university official to operate in their functions and responsibilities as well as join university activities. Employees work according to the organization's strategies, to meet the key performance indicators (KPIs) for success (Na-Nan, Panich, Thipnete, \& Rungrudee, 2016). Both public and private sectors need personnel that put in the time and efforts to work toward the organization's goals (Na-Nan, 2016; Na-Nan, Chaiprasit, \& Pukkeeree, 2017a). Sometimes, it requires working overtime or on the weekend; these are the behaviors beyond the role so-called "organizational citizenship behavior" (Organ, 1988). There are several factors in an organization that result in organizational citizenship behavior. Among them are justice and trust in the organization. Personnel expects to be equally treated by the management. This would lead to trust among the personnel, and when they have trust, no matter the supervisor or the organization, they would be glad to work with full potential.

Rajamangala University of Technology is a university in Thailand with nine different campuses. The workers in the university can be divided into academic staff and supporting staff. Presently, the university recruits personnel to work as officers and most of them are in generation $\mathrm{X}$ and generation $\mathrm{Y}$. They usually have different ages and work experiences. The staffs expect returns from the organization while the organization also expects some returns from the personnel. The organization expects the staff to work according to the set indicators. But beyond this, the organization requires all personnel to put some efforts to work and be willing to help the organization in extra-university activities. Staff expectation from the organization is career advancement, fair compensation from the organization and fair treatment from the management. If the staff expectations are met, they will be satisfied with the organization, express loyalty and perceive the organization as having justice and trust. Staff would actually reflect organizational citizenship behavior (Na-Nan \& Chalermtanakijkosol, 2012). Therefore, this led to the study on the influence of justice and trust on organizational citizenship behavior in Rajamangala University of Technology.

This study investigated the positive influence of justice and trust toward organizational citizenship behavior, the 
role of mediator variable of trust, and to compare the differences in the perception of generation $\mathrm{X}$ and generation $\mathrm{Y}$ on the influence justice and trust influences on organizational citizenship behavior.

\section{Literature Review}

\subsection{Organizational Citizenship Behavior}

Organizational citizenship behavior is a concept that explains the work behavior of personnel in an organization which leads to effectiveness in operation. Organizational citizenship behavior is the behavior that does not relate to role and responsibility but it is the behavior with special function (Smith, Organ, \& Near, 1983). From the literature review, Organizational citizenship behavior is the individual behavior reflecting roles in the organization, but this is not the job functions as assigned; it is the behavior that each staff wants to reflect without any expectations. The behavior could lead the organization toward efficiency in operation and organizational success (Organ, Podsakoff, \& MacKenzie, 2006; Podsakoff, MacKenzie, Paine, \& Bachrach, 2000). Every organization needs the personnel to reflect more positive behaviors beyond their work roles. It means that the organization will have the personnel with tie and loyalty in the organization and willing to make the organization outstanding than other organization and to promote strength of the organization (Ekowati, Troena, \& Noermijati, 2013; Saraih, Ali, \& Khalid, 2015). Organizational citizenship behavior is what a person can share with the colleagues to help in operational problems. It is the ability to give advice for decision making. Alzayed, Jauhar, and Mohaidin (2017) state that what the organization wants to gain from staff is the sacrifice of time to work and not waste time on personal things and pay attention to follow the rules and regulations placed by the organization and not to neglect responsibility, when faced with obstacles, and to seek for solutions with emotional control; having no conflict with colleagues, welcome changes and help the organization and offer suggestions for organizational development toward better efficiency (Carter, Mossholder, Feild, \& Armenakis, 2014; Ölçer, Florescu, \& Năstase, 2014). If all the personnel are satisfied in their job, perceived justice in organization and have trust in the organization, these factors would lead to the reflection of organizational citizenship behavior.

\subsection{Justice}

The theory of justice is to treat persons equally. When it requires making decision, we should hold on the core of justice. Since when a person acts on one thing, he/she usually compare to the other if what he/she gets in return is fair or not. Thus, organizational justice then refers to the perception of returns received from the organization with the appropriate consideration process and equally treat between persons (Greenberg, 1990; Greenberg \& Baron, 2000; Kanfer, 1990). Thus, the theory of justice in the organization as explained by Walster, Berscheid, and Walster (1976) in reference to the balance theory is that everyone needs to get high return thus, they try hard to seek for a big amount of return and help each other's to seek for theirs. Besides, Vroom's expectancy theory, uses hope to motivate people in the operation for the returns if job is done as planned (Vroom, 1964). Organizational justice is to know correctness and equality, and it is the consideration on the receiving returns set from the standard considering process. Organizational justice also considers treatment of people too (Folger \& Cropanzano, 1998; Sheppard, Lewicki, \& Minton, 1992). From the review of the literature it was found that justice is the expectation of the staff on the returns from the organization as fair consideration of equity with a valid and transparent criteria that can be checked (Saraih et al., 2015). When the personnel perceives justice in the organization or from leader, it brings satisfaction and, confidence in the leader and the organization and the willingness to work with full efforts toward the organizational goal (Colquitt, 2012; Khan \& Rashid, 2015; Zeinabadi \& Salehi, 2011). In each organization, personnel work toward success and can result from many factors; when working in the organization, people usually expect justice, which leads to the relationship with other factors. For example, organizational satisfaction, organizational commitment, motivation, etc. Adams (1965) stated that equity theory focuses on organizational justice that personnel can perceive the worth of justice in relation to their ability and knowledge compared to their colleagues. Next, the factor of justice related to compensation is rather not sufficient to reflect the whole organizational citizenship behavior. Thus, it requires forming the perception on the guideline for personnel compensation with procedural justice (Blodgett, Hill, \& Tax, 1997; Tahseen \& Akhtar, 2016) with the suitable criteria that are accepted by everyone in the organization. Besides, the good behavior that personnel reflects must also consider the perception of justice in the organization. It is the relationship with fair treatment of each other, so-called interactional justice. The perceived justice in the organization is the factor that creates trust in supervisor and organization onward. Many researchers have found that organizational justice has a positive relationship with organizational citizenship behavior at a statistical significant level (Cho \& Dansereau, 2010; Jafari \& Bidarian, 2012; Saraih et al., 2015; Wang \& Jiang, 2015; Zeinabadi \& Salehi, 2011). 


\subsection{Trust}

Trust in the organization is what people rely on it leads to cooperation in the use of resources for maximum efficiency (Healey, 2008). Trust is related to personnel's behavior in the organization relation (Lewicki, McAllister, \& Bies, 1998). In 1990, trust gained much interest in the study of behaviors between groups of people, persons, and organizations (Jones \& George, 1998). Trust is then a multidimensional approach concept that differs in sciences such as psychology, humanity, economic, societal, etc. (Lewicki \& Bunker, 1996). Trust comes from the perception of the actions of people that can be accepted under the situation and reasonable selection. Moreover, trust results from personnel's emotion that reflects care; it is expected to gain returns from that feeling (McAllister, 1995). From the Luhmann's concept related to trust, it is the concept generally accepted on trust related to interpersonal trust which is trust in the leader while organizational trust is the system trust. Luhmann (1979) explained that trust in the organization is to accept the goal and values of the organization and wish to continue working in the organization. Trust in a relationship is trust in the system and interpersonal, while trust in boss or leader can be assessed from interpersonal trust; while organization can be assessed from trust in the system. In the past literature review, it was found that trust in the organization is trust of the personnel their supervisors or management. It is the good relationship between people (Burke, Sims, Lazzara, \& Salas, 2007; Trong Tuan, 2012). When the personnel finds problems or obstacles in operation, they need help from colleagues, especially supervisors to help them solve the problem on time, also with a creative solution (Burke et al., 2007). The followers can place trust in their leader, and express their opinions in situations. Trust in the organization could come from secure and safe feeling in operation within the organization. Samadi, Wei, Seyfee, and Yusoff (2015) stated that the personnel perceives that they can trust the organization when they foresee career advancement, future security and well treatment from the organization. Trust in the organization then comes from the perception of personnel on the justice from their supervisor and organization, and this leads to trust in supervisor and organization. Personnel reflects more organizational citizenship behavior until finally, that good behavior would, in turn, become what everyone in the organization is willing to practice from generation to generation.

The previous research found that organizational trust has a positive relationship with organizational citizenship behavior at a statistical significant level (Aryee, Budhwar, \& Chen, 2002; Ertürk, 2007; Pillai, Schriesheim, \& Williams, 1999). Moreover, the result of mediator testing is different, so some research found that trust fully mediates (Aryee et al., 2002; Casimir, Waldman, Bartram, \& Yang, 2006; Ertürk, 2007), but sometimes found partial mediation (Aryee et al., 2002; Ertürk, 2007). So it is interesting to explore the role of trust mediator. This led to the assumptions in this study.

\subsection{Generation}

In each organization, there is personnel with diversity in all aspects such as age, qualification, education, family, etc. At each stage of life, we are different in behaviors, learning, as well as ways of living. Considering the age of each person, we can categorize them into three main generations. First, Baby Boomer is the group the born during 1946-1964 (Andert, 2011). This group of people work hard for the organization, pay attention to the rules and are patient in a rough time. Next is the group of generation X, born in 1965-1980 (Lavoie-Tremblay, Leclerc, Marchionni, \& Drevniok, 2010); they were born in the age with high competition in economy and did not tend to have many children, they have high confidence, with vision and can help themselves well, seeking for knowledge and experience, paying attention to work and family. The last group is generation $\mathrm{Y}$, born in 1980-1994 (Lavoie-Tremblay et al., 2010). This group of people usually find reasons, show out, love convenience, use advanced technology, search for the job they like and live freely; if they work hard, it should provide high returns, they love freedom in work, measuring performance from job done, they do not like fix work hours, etc. (Foot \& Stoffman, 1996).

Personnel operating in each organization have diversity in age among the generation of baby boomer, generation $\mathrm{X}$, and generation Y. Each generation is different by age and work experiences, even their life experience (De Meuse, Bergmann, \& Lester, 2001). When these generations have to work together, they have to adjust to each other to learn the differences and accept them. Seniors could reflect organizational citizenship behavior by helping in work training for new staff and giving suggestion when there is an operational problem (Andert, 2011). At the same time, juniors can also give suggestion the seniors as well, such as helping them on advanced technology and exchanging knowledge between each other. Besides, the important thing for each generation is to treat each other with honor which is a crucial thing for both generations to work together (Yu \& Miller, 2005).

The importance of the perception of organizational justice and organizational trust that result in the organizational citizenship behavior leads to the following conceptual model (Figure 1) and research hypotheses. 
H1: Justice Dimension has a positive effect on organizational citizenship behavior.

H2: Trust Dimension has a positive effect on organizational citizenship behavior.

H3: Justice Dimension has a positive effect on trust.

H4: Trust mediates the effect between justice and organizational citizenship behavior.

H5: Generation X and Generation Y perceive justice and trust differently in relation to organizational citizenship behavior.

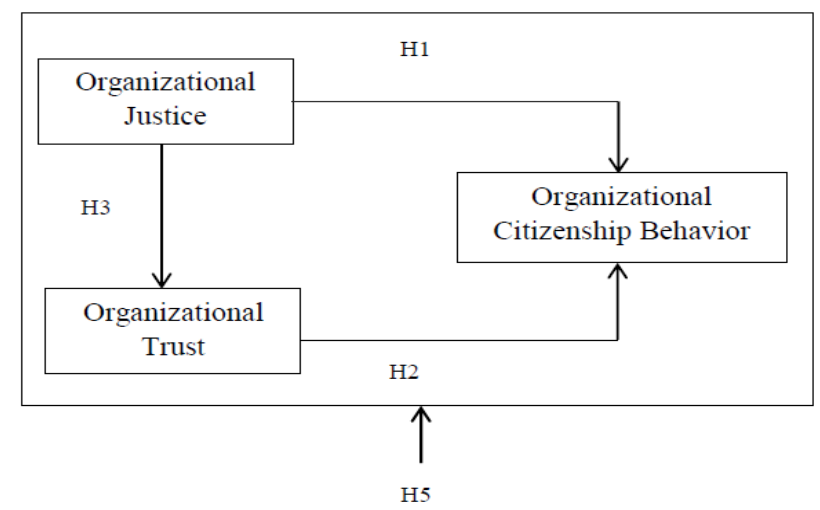

Figure 1. Conceptual Model

\section{Research Methodology}

The population and sample group in this study were the university staff who work in nine universities of Rajamangala University of Technology (Isan, Thanyaburi, Krungthep, Tawan-Ok, Lanna, Rattanakosin, Phra-Nakorn, Suvarnabhumi, and Sri-Vichai). For the sample group, Hair, Black, Babin, and Anderson (2010) suggest that the Structural Equation Modeling (SEM) analysis shall adopt more than 150 respondents. The researcher chose a sample size of 470 people. By $74.3 \%$ of questionnaire respondents were females, $33.6 \%$ of them aged between 32-36 years old and 52.1\% graduated with Master Degree.

The questionnaire was adapted from the research questions of Colquitt (2012) relating to justice (distributive justice, procedural justice, and interactional justice) containing 15 question items; they were questions related to distributive justice, the consideration and appropriate returns; on procedural justice, the questions related to the equality in the process used to consider the returns, rewards, and on interactional justice, the questions related to communications for good understanding in operation, performance evaluation, backup data, and data exchange in the organization. For the questionnaire about trust (trust in chief, and trust in faculty), the researcher adapted questions from the study of Nyhan and Marlowe Jr (1997); Robinson (1996). Fourteen questions about trust in chief; the questions on the feeling of confidence to rely on others to affect performance, communication, and cooperation for solutions to problems or any obstacles. The questions about trust in the faculty were questions on the feeling of confidence of personnel toward the organization, forming relationship and loyalty in the organization which leads to the expectation of persons toward the success of work in the future. Trust in the organization related to the relationship of any units in the organization, colleagues, all levels of supervisor and for organizational citizenship behavior (altruism, courtesy, conscientiousness, sportsmanship, and civic virtue) the questions were adapted from the research by Organ (1988). There are 24 question items related to altruism; they are questions on the behavior made by voluntary to help the others, courtesy behavior to pay attention to solve the conflicts of people in the unit for not to fight with the colleages, to offer the reasonable opinion, and mercy the other; the questions on conscientiousness are about the work on time set, knowing one's role and responsibility, put efforts and sacrifice time to work toward achievement; the questions on sportsmanship are about the personnel behavior to endure for problems and obstacles or inconvenient in the operation; and the questions on civic virtue are about the personnel behavior toward the organization on cooperation, welcome and fully cooperate for the successful organization development.

The questionnaires contain questions that conformed to the research objectives of this study. Results measurement and assessment was done based on Likert scale ( $1=$ strongly disagree to 5 strongly agree). The questionnaire was proofed by the experts before administration. For the measuring on generation, the groping was according to the age of respondents; for age between 22-36 years old were considered as generation Y, age 
from 37-51 years old was generation X, and more than 51 years old was the baby boomer (BB) generation.

The researcher analyzed the data by using structural equation modeling (SEM). Thus, before the structural model analysis, the researcher checked the conformity of empirical data via confirmatory factor analysis. The indicators used in conformity measurement of the model consisted of CMIN/DF, comparative fit index (CFI), normed fit index (NFI), the goodness of fit (GFI), adjusted goodness of fit index (AGFI), and root square mean of approximation (RMSEA).

\section{Results}

\subsection{Confirmatory Factor Analysis (CFA)}

The researcher analyzed the empirical data by CFA. The values appear as follows: $C M I N=44.366, d f=24$, $\mathrm{p}=0.007, \mathrm{CMIN} / \mathrm{df}=1.849, \mathrm{GFI}=0.981, \mathrm{AGFI}=0.957, \mathrm{NFI}=0.985, \mathrm{CFI}=0.993$, and $\mathrm{RMSEA}=0.043$. These values are in accordance with the acceptance criteria which is CMIN/df should less than 3,GFI, AGFI, NFI, and CFI should more than 0.90, and RMSEA should less than 0.10 (Hair et al., 2010).

\subsection{Structural Model}

The researcher tested the hypotheses by SEM, the testing results reflect that indicators conform well as follows: $\mathrm{CMIN}=45.470, \mathrm{df}=25, \mathrm{p}=0.007, \mathrm{CMIN} / \mathrm{df}=1.819, \mathrm{GFI}=0.982, \mathrm{AGFI}=0.959, \mathrm{NFI}=0.987, \mathrm{CFI}=0.993$, and RMSEA $=0.042$. According to Hypothesis 1 justice dimension has a positive effect on organizational citizenship behavior. Thus $\mathrm{H} 1$ is supported $(\beta=.382, \mathrm{p}=<0.05)$. Hypothesis 2 , trust dimension has a positive effect on organizational citizenship behavior. Thus $\mathrm{H} 2$ is supported $(\beta=.251, \mathrm{p}=<0.05)$. Next, Hypothesis 3 , justice dimension has a positive effect on trust it found that this $\mathrm{H} 3$ is supported $(\beta=.870, \mathrm{p}=<0.05)$. Hypothesis 4 , trust mediates the effect between justice and organizational citizenship behavior, thus trust partially mediates the effect between justice and organizational citizenship behavior. Lastly, H5 generation X and generation $\mathrm{Y}$ perceive justice and trust differently in relation to organizational citizenship behavior the effect of justice, trust, and organizational citizenship behavior between generation $\mathrm{X}$ and generation $\mathrm{Y}$ is different (Table 1).

In table 2, justice has a statistical significant effect on trust and organizational citizenship behavior. Similarly, in the generation $\mathrm{Y}$, justice has statistical significant effect on trust and organizational citizenship behavior. When comparing the differential variables between generation $\mathrm{X}$ and generation $\mathrm{Y}$, generation $\mathrm{Y}$ perceived the effect of justice on organizational trust more than generation $X$; generation $X$ perceived the effect of justice on organization citizenship behavior more than generation $\mathrm{Y}$.

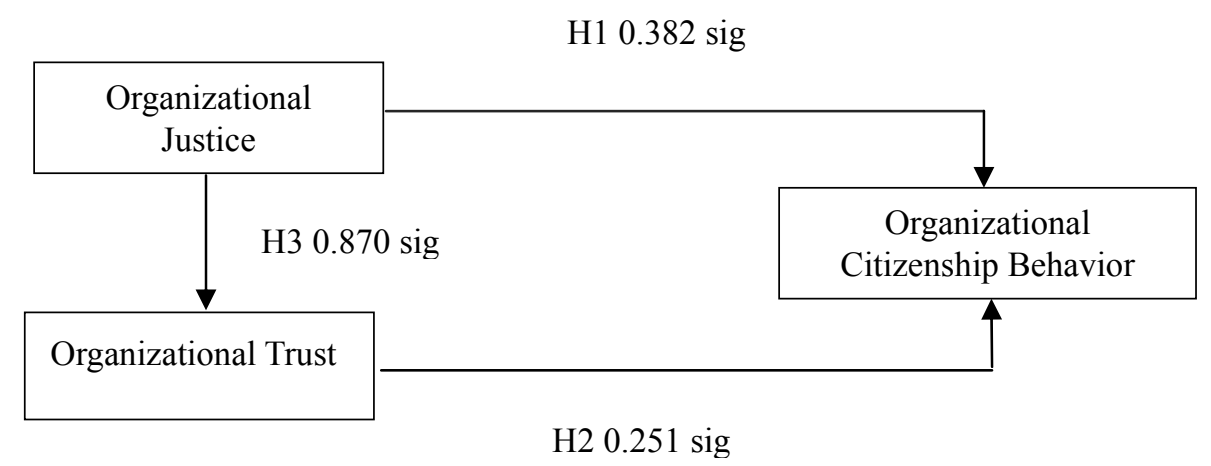

Figure 2. Hypothesis test

Table 1. Testing path analysis

\begin{tabular}{llllcccccc}
\hline & & \multicolumn{2}{c}{ Unconstrained } & \multicolumn{2}{c}{ Constrained } & \multicolumn{3}{c}{ Diff } & \\
\cline { 3 - 7 } & & & $\mathrm{x}^{2}$ & $\mathrm{df}$ & $\mathrm{x}^{2}$ & $\mathrm{df}$ & $\triangle \mathrm{x}^{2}$ & $\triangle \mathrm{df}$ & \\
\hline Trust & $<---$ & Justice & 97.849 & 50 & 107.373 & 51 & 9.524 & 1 & sig \\
OCB & $<---$ & Justice & 97.849 & 50 & 104.922 & 51 & 7.073 & 1 & sig \\
OCB & $<---$ & Trust & 97.849 & 50 & 106.397 & 51 & 8.548 & 1 & sig \\
\hline
\end{tabular}

Note: $\mathrm{OCB}=$ organizational citizenship behavior, $\mathrm{p}>0.05(3.84)$ 
Table 2. Regression weight

\begin{tabular}{|c|c|c|c|c|c|c|c|c|}
\hline & & & \multicolumn{3}{|c|}{ Generation X } & \multicolumn{3}{|c|}{ Generation Y } \\
\hline & & & Estimate & C.R. & $\mathrm{P}$ & Estimate & C.R. & $\mathrm{P}$ \\
\hline Trust & $<---$ & Justice & 0.859 & 8.545 & $* * *$ & 0.878 & 15.77 & $* * *$ \\
\hline OCB & $<---$ & Justice & 0.439 & 2.07 & $0.038^{* *}$ & 0.392 & 2.529 & $0.011 * *$ \\
\hline OCB & $<---$ & Trust & 0.236 & 1.132 & 0.258 & 0.219 & 1.432 & 0.152 \\
\hline
\end{tabular}

Note: $\mathrm{OCB}=$ organizational citizenship behavior

\section{Discussions and Conclusion}

The finding showed a positive impact between variables in the context of the university. The result of the testing showed that justice and trust have a statistical significant effect on organizational citizenship behavior. It means the personnel will reflect the behavior to help colleagues, create solutions to problems when there is a conflict and provide an opinion to solve problems, patience with each other as well as join in activities that the organization plans. These behaviors are influenced by justice and trust in the leader and organization. This conforms to the research by Jafari and Bidarian (2012) on the relationship between justice and organizational citizenship behavior. The study result stated that trust from the employee of the university has a significant relationship with organizational citizenship behavior. This also conforms to Singh and Srivastava (2016) who studied 303 samples of high, middle and low level managers of the service industry business and found that trust in the organization has a significant positive relationship with organizational citizenship behavior. Besides, it was found from the study that justice has a statistical significant effect on trust; conforming to the study by Bidarian and Jafari (2012) who found that the relationship of justice and trust has a statistical significance by trust in the organization leading to higher justice in the organization too. For the mediator testing, it was found that trust partially mediates the effect between justice and organizational citizenship behavior. Furthermore, this study found that generation $\mathrm{X}$ and generation $\mathrm{Y}$ perceive the effect of justice and trust on organizational citizenship behavior differently.

The result of this study shows that Rajamangala University of Technology staff perceived the influence of justice and trust toward organizational citizenship behavior as significant. That is, the university personnel perform their roles beyond work duties from the perception of organizational trust and justice. The university requires personnel to put efforts to work toward efficiency and set goals. Personnel will reflect all good behaviors when they are satisfied with their job in the university. Satisfaction also results from fair salary for their knowledge, ability and work experiences (Na-Nan, Chaiprasit, \& Pukkeeree, 2017b). Salary shall conform to the position, responsibilities, qualifications and work experiences. Thus, it must rise from the fair compensation consideration process with justice and be able to clarify if personnel are in doubt. The personnel should participate in criteria setting. Besides, being treated with honor from the supervisor, equity is required by staff. When they receive good care from the supervisor, the behavior beyond job role and responsibility will increase. When personnel perceives justice in the organization, they will develop trust in the organization, and when faced with any work problems in the university, they will refer for help from the supervisor with trust that they would have the chance to share opinions toward a successful organizational development.

Research on role and responsibilities of personnel who work in the organization shall be done in the future. Thus, the researcher sees that future research must be conducted on organizational citizenship behavior but focusing on other factors such as leadership, organizational commitment, job satisfaction, happy work life, etc.

\section{References}

Adams, J. S. (1965). Inequity in social exchange. Advances in experimental social psychology, 2, 267-299.

Alzayed, M., Jauhar, J., \& Mohaidin, Z. (2017). The mediating effect of affective organizational commitment in the relationship between organizational justice and organizational citizenship behavior: A conceptual model. Asian Social Science, 13(5), 165-175. https://doi.org/10.5539/ass.v13n5p165

Andert, D. (2011). Alternating leadership as a proactive organizational intervention: Addressing the needs of the baby boomers, generation Xers and Millennials. J. of Leadership, Accountability and Ethics, 8(4), 67-83.

Aryee, S., Budhwar, P. S., \& Chen, Z. X. (2002). Trust as a mediator of the relationship between organizational justice and work outcomes: Test of a social exchange model. Journal of Organizational Behavior, 23(3), 267-285. 
Bidarian, S., \& Jafari, P. (2012). The relationship between organizational justice and organizational trust. Procedia - Social and Behavioral Sciences, 47, 1622-1626.

Blodgett, J. C., Hill, D. J., \& Tax, S. S. (1997). The effects of distributive procedural, and interactional justice on postcomplaint behavior. Journal of Retailing, 73(2), 185-210.

Burke, C. S., Sims, D. E., Lazzara, E. H., \& Salas, E. (2007). Trust in leadership: A multi-level review and integration. The Leadership Quarterly, 18(6), 606-632. https://doi.org/10.1016/j.leaqua.2007.09.006

Carter, M. Z., Mossholder, K. W., Feild, H. S., \& Armenakis, A. A. (2014). Transformational leadership, interactional justice, and organizational citizenship behavior: The effects of racial and gender dissimilarity between supervisors and subordinates. Group \& Organization Management, 39(6), 691-719.

Casimir, G., Waldman, D. A., Bartram, T., \& Yang, S. (2006). Trust and the relationship between leadership and follower performance: Opening the black box in Australia and China. Journal of Leadership \& Organizational Studies, 12(3), 68-84.

Cho, J., \& Dansereau, F. (2010). Are transformational leaders fair? A multi-level study of transformational leadership, justice perceptions, and organizational citizenship behaviors. The Leadership Quarterly, 21(3), 409-421. https://doi.org/10.1016/j.leaqua.2010.03.006

Colquitt, J. A. (2012). Organizational justice (Vol. 1): Oxford University Press.

De Meuse, K. P., Bergmann, T. J., \& Lester, S. W. (2001). An investigation of the relational component of the psychological contract across time, generation, and employment status. Journal of Managerial Issues, $13(1)$.

Ekowati, V. M., Troena, E. A., \& Noermijati, N. (2013). Organizational citizenship behavior role in mediating the effect of transformational leadership, job satisfaction on employee performance: Studies in PT Bank Syariah Mandiri Malang East Java. International Journal of Business and Management, 8(17). https://doi.org/10.5539/ijbm.v8n17p1

Ertürk, A. (2007). Increasing organizational citizenship behaviors of Turkish academicians: Mediating role of trust in supervisor on the relationship between organizational justice and citizenship behaviors. Journal of Managerial Psychology, 22(3), 257-270.

Folger, R. G., \& Cropanzano, R. (1998). Organizational Justice and Human Resource Management. SAGE Publications.

Foot, D. K., \& Stoffman, D. (1996). Boom, Bust \& Echo: How to Profit from the Coming Demographic Shift. Toronto: Macfarlane Walter \& Ross.

Greenberg, J. (1990). Organizational justice: Yesterday, today, and tomorrow (Vol. 16).

Greenberg, J., \& Baron, R. A. (2000). Behavior in Organizations: Understanding and Managing the Human Side of Work. Prentice Hall.

Hair, J. F., Black, W. C., Babin, B. J., \& Anderson, R. E. (2010). Multivariate data analysis (6th ed.). Upper Saddle River, New Jersey: Peason Prentice Hall.

Healey, J. (2008). Radical Trust: How today's great leaders convert people to partners. Wiley.

Jafari, P., \& Bidarian, S. (2012). The Relationship between organizational justice and organizational citizenship behavior. Procedia - Social and Behavioral Sciences, 47, 1815-1820. https://doi.org/10.1016/j.sbspro.2012.06.905

Jones, G. R., \& George, J. M. (1998). The experience and evolution of trust: Implications for cooperation and teamwork. Academy of Management Review, 23(3), 531-546.

Kanfer, R. (1990). Motivation theory and industrial and organizational psychology. Handbook of industrial and organizational psychology, 1(2), 75-130.

Khan, S. K., \& Rashid, M. Z. A. (2015). The Mediating Effect of Organizational Commitment in the Organizational Culture, Leadership and Organizational Justice Relationship with Organizational Citizenship Behavior: A Study of Academicians in Private Higher Learning Institutions in Malaysia. International Journal of Recent Advances in Organizational Behaviour and Decision Sciences (IJRAOB), 1(2), 335-359.

Lavoie-Tremblay, M., Leclerc, E., Marchionni, C., \& Drevniok, U. (2010). The needs and expections of generation Y nurses in the workplace. Journal for Nurses in Staff Development, 26(1), 2-8. 
Lewicki, R. J., \& Bunker, B. B. (1996). Developing and maintaining trust in work relationships. Trust in organizations: Frontiers of theory and research, 114, 139.

Lewicki, R. J., McAllister, D. J., \& Bies, R. J. (1998). Trust and distrust: New relationships and realities. Academy of Management Review, 23(3), 438-458.

Luhmann, N. (1979). Trust; And, Power: Two Works. Wiley.

McAllister, D. J. (1995). Affect-and cognition-based trust as foundations for interpersonal cooperation in organizations. Academy of Management Journal, 38(1), 24-59.

Na-Nan, K. (2016). Performance management system of SMEs in Thailand. International journal of Economics Research, 13(4), 1641-1658.

Na-Nan, K., Chaiprasit, K., \& Pukkeeree, P. (2017a). Influences of workplace environment factors on employees' training transfer. Industrial and Commercial Training, 49(6), 303-314. https://doi.org/10.1108/ICT-02-2017-0010

Na-Nan, K., Chaiprasit, K., \& Pukkeeree, P. (2017b). Performance management in SME high-growth sectors and high-impact sectors in Thailand:Mixed method research. International Journal of Engineering Business Management, 9, 1847979017718451. https://doi.org/10.1177/1847979017718451

Na-Nan, K., \& Chalermtanakijkosol, K. (2012). A Causal relationship model of factors affecting employee engagement and performance. RMUT Global Business and Economics Review, 7(1), 145-168.

Na-Nan, K., Panich, T., Thipnete, A., \& Rungrudee, K. (2016). Influence of Job Characteristics, Organizational Climate, Job Satisfaction and Employee Engagement that Affect the Organizational Citizenship Behavior of Teachers in Thailand. The Social Sciences, 11(18), 4523-4533.

Nyhan, R. C., \& Marlowe Jr, H. A. (1997). Development and psychometric properties of the organizational trust inventory. Evaluation Review, 21(5), 614-635.

Ölçer, F., Florescu, M. S., \& Năstase, M. (2014). The effects of transformational leadership and emotional intelligence of managers on organizational citizenship behaviors of employees. Review of International Comparative Management Volume, 15(4), 385-401.

Organ, D. W. (1988). Organizational citizenship behavior: The good soldier syndrome. Lexington Books/DC Heath and Com.

Organ, D. W., Podsakoff, P. M., \& MacKenzie, S. B. (2006). Organizational Citizenship Behavior: Its Nature, Antecedents, and Consequences. Thousand Oaks, CA: SAGE Publications, Inc.

Pillai, R., Schriesheim, C. A., \& Williams, E. S. (1999). Fairness perception and trust as mediatiors for transformational and transactionl leadership: A two-sample study. Journal of Management, 25(6), 897-933.

Podsakoff, P. M., MacKenzie, S. B., Paine, J. B., \& Bachrach, D. G. (2000). Organizational citizenship behaviors: A critical review of the theoretical and empirical literature and suggestions for future research. Journal of Management, 26(3), 513-563.

Robinson, S. L. (1996). Trust and breach of the psychological contract. Administrative Science Quarterly, 41, 574-599.

Samadi, B., Wei, C. C., Seyfee, S., \& Yusoff, W. F. W. (2015). Conceptual model of ofganizational trust and knowledge sharing behavior among multigenerational employees. Asian Social Science, 11(9), 32-42. https://doi.org/10.5539/ass.v11n9p32

Saraih, U. N., Ali, H., \& Khalid, S., Annuar. (2015). The developement of teachers' career in relationship ot OCB and Justice: A study in Malaysia. Asian Social Science, 11(24), 62-71. https://doi.org/10.5539/ass.v11n24p62

Sheppard, B. H., Lewicki, R. J., \& Minton, J. W. (1992). Organizational justice: the search for fairness in the workplace. New York; Toronto; New York: Lexington Books; Maxwell Macmillan Canada; Maxwell Macmillan International.

Singh, U., \& Srivastava, K. B. L. (2016). Organizational trust and organizational citizenship behavior. Global Business Review, 17(3), 594-609.

Smith, C. A., Organ, D. W., \& Near, J. P. (1983). Organizational citizenship behavior: Its nature and antecedents. Journal of Applied Psychology, 68(4), 653-663. 
Tahseen, N., \& Akhtar, M. S. (2016). Impact of organizational justice on citizenship behavior: Mediating role of faculty trust. Pakistan Journal of Commerce and Social Sciences, 10(1), 104-121.

Trong Tuan, L. (2012). The linkages among leadership, trust, and business ethics. Social Responsibility Journal, 8(1), 133-148. https://doi.org/10.1108/17471111211196629

Vroom, V. H. (1964). Work and motivation. New York: Wiley.

Walster, E., Berscheid, E., \& Walster, G. W. (1976). New directions in equity research. Advances in experimental social psychology, 9, 1-42. https://doi.org/10.1016/S0065-2601(08)60057-X

Wang, T., \& Jiang, H. (2015). The mediating effects of organizational and supervisor identification Public Personnel Management, 44(4).

Yu, H. C., \& Miller, P. (2005). Leadership style: the X generation and baby boomers compared in different cultural contexts. Leadership \& Organization Development Journal, 26(1), 35-50. https://doi.org/10.1108/01437730510575570

Zeinabadi, H., \& Salehi, K. (2011). Role of procedural justice, trust, job satisfaction, and organizational commitment in organizational citizenship behavior (OCB) of teachers: Proposing a modified social exchange model. Procedia - Social and Behavioral Sciences, 29, 1472-1481. https://doi.org/10.1016/j.sbspro.2011.11.387

\section{Copyrights}

Copyright for this article is retained by the author(s), with first publication rights granted to the journal.

This is an open-access article distributed under the terms and conditions of the Creative Commons Attribution license (http://creativecommons.org/licenses/by/4.0/). 